\title{
Plantkunde-onderrig in Gautengse skole: 'n Opwindende uitdaging?
}

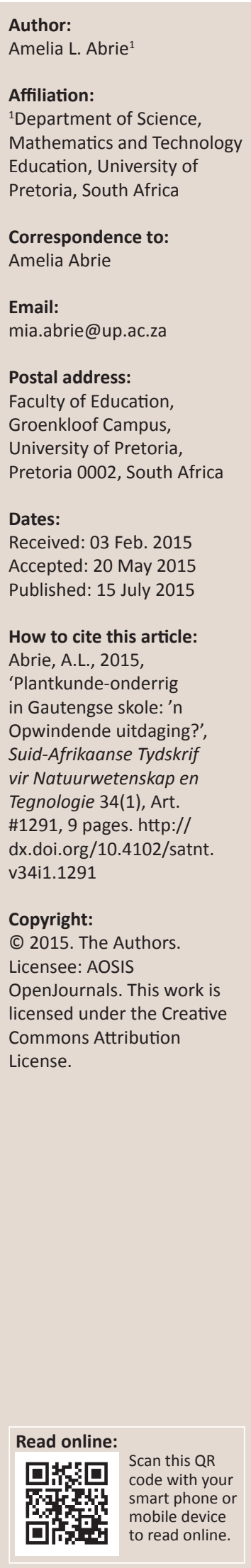

Positiewe gesindheid by onderwysers en leerders kan 'n lewenslange belangstelling in plante aanwakker. Tog word Plantkunde wêreldwyd as 'n ongewilde vak gereken. Studies in die Verenigde State van Amerika en elders het getoon dat leerders die vak as vervelig beskou. In die literatuur word plantblindheid, soösentrisme en soöchauvinisme wyd hiervoor geblameer. In hierdie studie is daar deur onderhoude met onderwysers en vraelyste aan leerders gepoog om te bepaal wat die status van Plantkunde in sekondêre skole in Tshwane, Gauteng is. Lewenswetenskappe-onderwysers was baie positief oor hulle vak, maar van die deelnemers het negatiewe houdings teenoor die Plantkunde-inhoud geopenbaar. Onderwysers was dit eens dat leerders, met enkele uitsonderings na, nie van plantstudies hou nie en hierdie bevinding is gestaaf deur die vraelyste wat die leerders ingevul het. Verskeie struikelblokke wat die onderrig van Plantkunde bemoeilik, is geïdentifiseer. Krathwohl, Bloom en Masia se klassifikasie van die affektiewe domein en die holistiese benadering tot Lewenswetenskappeonderrig is gebruik om die bevindings in perspektief te plaas.

Botany teaching in Gauteng schools: An exciting challenge? A positive attitude in teachers and learners can create a life-long interest in plants. Worldwide, Botany is seen as an unpopular subject and studies in the United States of America and elsewhere have shown that learners find the subject boring. Plant blindness, soöcentrism and soöchauvinism are widely blamed for this situation. In this study, the status of Botany in secondary schools in Tshwane, Gauteng, was investigated, using interviews with teachers and learner questionnaires. Life sciences teachers are positive about their subject, but some of the participants revealed negative attitudes towards the Botany content. The teachers agreed that the learners, with a few exceptions, did not like plant studies and this finding was confirmed by the questionnaires that were completed by the learners. A number of challenges, increasing the difficulties of teaching Botany were identified. Krathwohl, Bloom and Masia's classification of the affective domain and the holistic approach to Life Sciences education were employed to provide perspective to the findings.

\section{Inleiding}

Die mens se daaglikse aktiwiteite, antropogeniese klimaatsverandering, oorbevolking en verstedeliking is voortdurende bedreigings vir die oorlewing van plantspesies en die behoud van diversiteit. Alhoewel baie mense nie in hulle daaglikse bedrywighede veel aandag gee aan die impak wat hulle op hulle omgewing en op die res van die aarde het nie, begin almal die gevolge van die roekelose verbruik van hulpbronne voel. Katastrofes soos vloede, droogtes en uiterste weerverskynsels word aan aardverwarming toegeskryf, soms sonder enige wetenskaplike bewyse daarvoor. Daar bestaan dus 'n beduidende behoefte aan inligting om die algemene publiek nie net bewus te maak van die stand van kennis oor hierdie verskynsels nie, maar ook om wanopvattings aan te pak.

Die mens se voortbestaan is regstreeks afhanklik van die voortbestaan van plante en die gesondheid van die ekostelsel. Plante voorsien die mens van lewensnoodsaaklike hulpbronne wat dikwels as vanselfsprekend aanvaar word, soos suurstof, voedsel, kleding, boumateriaal en brandstof (in die vorm van hout en steenkool) en die estetiese voordele wat dit bied, is onbetwisbaar. Plante is die mens se hoofbron van voedsel en ongeveer 4 miljard mense is van ' $n$ plantgebaseerde dieet afhanklik, in vergelyking met 2 miljard mense wat van ' $n$ diergebaseerde dieet leef (Pimentel \& Pimentel 2003). Omdat die produksie van vleis ook indirek van plante afhanklik is, is feitlik alle menslike voedsel direk of indirek van plante afkomstig. Die chroniese ondervoeding van bykans 870 miljoen mense, wat $12 \%$ van die wêreldbevolking verteenwoordig (FAO, WFP \& IFAD 2012), kan slegs aangepak word as die ekostelsel die nodige hulpbronne kan voorsien. Die omgewingsinsette wat egter benodig word vir 'n diergebaseerde dieet is minder volhoubaar as 
die insette nodig vir 'n plantgebalanseerde dieet (Pimentel \& Pimentel 2003). Plante vorm dus 'n noodsaaklike aspek van die volhoubaarheid van kosvoorsiening.

Ondanks die onbetwiste waarde wat plante vir die mens het, bly plante vir'n groot deel van die bevolking bykans onsigbaar en ongewaardeer, alhoewel hulle 'n groot invloed op die onderbewuste van mense het. 'n Onlangse studie het getoon dat die teenwoordigheid van plante in 'n kantooromgewing die lewensgehalte van kantoorwerkers beduidend verbeter en ook werknemers se persepsies van werkstevredenheid, konsentrasie en luggehalte verbeter. Hulle produktiwiteit het met byna 15\% verhoog (University of Exeter 2014). Mense se groeiende begeerte om 'n positiewe impak op die omgewing en die natuur te hê, vind maklik uitdrukking in veldtogte om sigbare, groot soogdiere soos die renoster te red. Tog is daar min veldtogte om die Middelburg-broodboom (Encephalartos middelburgensis) van uitwissing te red, ondanks die feit dat daar minder as 350, moontlik slegs 120 individue, in die natuur oor is (Donaldson 2010; SANBI 2014). Plante was nie altyd so geringgeskat nie en Hershey (1996) beskryf hoe plantkunde aan die begin van die vorige eeu 'n baie populêre vakgebied was. Plantkundiges staan dus voor'n opwindende uitdaging om die publiek se bewustheid van plante en die voordele wat plante vir die mens inhou te verhoog.

Tydens my voorgraadse studies, onder die invloed van 'n inspirerende dosent, het my belangstelling in die waarde van plante ontwaak. Die subtiele maniere waarop plante, wat vasgeanker staan in die grond, tog kan groei, na water en voedingstowwe 'soek' en hulleself selfs teen predasie verweer, het my met verwondering gevul, maar na my studies het ek, as jong onderwyser en later as dosent in voorgraadse Plantkunde, wisselende sukses gehad om waardering vir plante aan my leerders en studente oor te dra. Hoe kan jong mense so min in plante belangstel? Die meeste van my leerders en studente was voorwaar blind vir plante, terwyl sommiges selfs getwyfel het of plante leef! In lesse oor respirasie moes leerders daaraan herinner word dat 'alle lewende organismes respireer en dat plante ook lewend is'. Tog, wanneer 'n mens die beskrywings van Plantkundekursusse in die brosjures van vooraanstaande universiteite lees, is dit amper ondenkbaar dat die vak nie gewilder is nie. Bestaande literatuur wys dat daar voorheen studies oor die ongewildheid van Plantkunde gedoen is, maar ' $n$ uitgebreide literatuurstudie toon aan dat so 'n studie nog nie in SuidAfrika, 'n land bekend vir sy besondere natuurskoon en ryk plantbiodiversiteit, gedoen is nie.

\section{Literatuurstudie}

Schneekloth het in 1989 reeds die neiging om plante as 'n onbeduidende agtergrond vir dierelewe te sien, opgemerk en dit onder andere toegeskryf aan 'n skeiding tussen ervaring en kennis, asook aan antroposentrisme. Wandersee en Schussler (1999) het die neologisme 'plantblindheid' geskep om die onvermoë te beskryf om die belangrikheid van plante raak te sien, ter wille van die omgewing sowel as van die mens; die onvermoë om die estetika van plante te waardeer of om hulle unieke biologiese kenmerke te herken; en 'n misplaaste neiging om plante te sien as ondergeskik aan diere en onwaardig om aandag aan te skenk. Hulle skryf die onderverteenwoordiging van Plantkunde in die biologiekurrikula ook aan plantblindheid toe. Die 'simptome' van plantblindheid sluit volgens Wandersee en Schussler (1999) ook die volgende in: 'n gebrek aan kennis van die behoeftes van plante om te oorleef, die praktiese kundigheid om plante te kweek, die bewustheid van plante in die gemeenskap (hier in die wetenskaplike sin gebruik!), die rol van plante in die koolstofsiklus, asook die estetiese kwaliteite van plante ten opsigte van hulle aanpassing, ko-evolusie, kleure, verspreiding, diversiteit, groeigewoontes, reuke, groottes, klanke, spasiëring, krag, simmetrie, tasbaarheid, smake en teksture. Hierdie 'simptome' leen hulle daartoe om deur goed beplande onderrig en inligtingsveldtogte verlig te word.

Wandersee en Schussler $(1999,2001)$ skryf plantblindheid gedeeltelik toe aan die beperkings van die menslike visuele persepsie en beweer dat die probleem nie noodwendig spruit uit soöchauvinisme en die soösentriese gebruik van voorbeelde (sien later) om biologiese begrippe te verduidelik nie. Hulle haal aan uit vorige studies (Norretranders 1998:126 in Wandersee \& Schussler 2001) wat daarop gewys het dat die mens slegs ' $n$ fraksie van die data wat deur die oog waargeneem word, bewustelik verwerk en waarneem. Die mens onthou ook slegs dit waaraan hy aandag gee en waaraan hy waarde heg. Ons aandag word dus gefokus op wat vir ons relevant is (Rugg 1998:1151 in Wandersee \& Schussler 2001). 'n Gebrek aan kennis en belangstelling sal dus 'n persoon se waarnemingsvermoë negatief beïnvloed. Dougherty het reeds in 1979 aangetoon dat kinders in Westerse kulture nie die name van plante ken nie, maar verwys na bos, of boom of gras, terwyl Barman et al. (2006) bevind het dat K-8-leerders bome of plante sonder blomme nie as plante beskou nie. Alhoewel die plantwêreld vir die kundige vol interessante patrone en kleure is, lyk plante vir die leek skynbaar chromaties en ruimtelik homogeen en boonop staties, in teenstelling met diere (Wandersee \& Schussler 1999) en die mens (Schneekloth 1989), waaraan heelwat aandag gegee word. 'n Feit wat ook nie uit die oog verloor moet word nie, is dat diere en mense, en nie plante nie, potensieel gevaarlik of mensvretend kan wees!

Argumente dat plante slegs raakgesien word indien daar blomme teenwoordig is, hou nie water nie, aangesien plante in elke seisoen aantreklike eïenskappe vertoon: van botsels wat die lente aankondig, bloeisels en blomme, tot die skouspel van blare wat in die herfs verkleur (Hershey 2002). Min mense het betekenisvolle en doelbewuste interaksie met plante, wat lei na 'n onvermoë om plantname te onthou en plante te herken (Wandersee \& Schussler 2001). Die implikasie hiervan is dat leerders steeds aan aandaggebrekkige plantblindheid (inattentional plant blindness) sal ly as 'n entoesiastiese plantmentor hulle aandag nie doelbewus op plante vestig en hulle lei om 'n waardering vir plante te ontwikkel nie.

Hershey (2002) gee toe dat die beperkings van menslike visuele persepsie moontlik een oorsaak van plantblindheid kan wees, 
maar voel dat soösentrisme, waar basiese biologiese konsepte verduidelik word deur na dierevoorbeelde te verwys sonder om plantvoorbeelde te noem, en soöchauvinisme genoegsame verduidelikings bied. Soöchauvinisme is ' $n$ term wat Bozniak in 1994 ontwikkel het om die oormatige fokus van aandag op diere ten koste van plante te beskryf. Kinders kry byvoorbeeld oulike opgestopte diertjies as geskenke, maar selde of ooit 'n opgestopte blom! Gedurende 'n onlangse konferensie in die Kruger Nasionale Park het kongresgangers opgewonde al die diere gelys wat hulle op die wildritte gesien het, maar geen plante nie. Een persoon het gesê: 'Ons is hier om die diere te sien' en 'n ander het gesê: 'Ons het niks gesien nie', ondanks die feit dat die noordelike deel van die Krugerpark dig bebos is, met mopaniebome, gras- en ander plantspesies, veral in die rivierlope. Dit is ongelukkig nie uitsonderlik nie, soos die titel van Schneekloth se 1989-artikel aandui: 'Where did you go? The forest. What did you see? Nothing'. Soöchauvinisme word verder vererger deur die gebrek aan inligting oor plante op gewilde televisieprogramme, insluitende dokumentêre programme op die betaalkanaal DSTV. Baie tyd sal aan dokumentêre programme oor haaie of krokodille gewy word, maar selde aan plante.

Soösentrisme, soöchauvinisme en antroposentrisme is uit 'n wetenskaplike uitgangspunt nie regverdigbaar nie, aangesien alle diere, insluitende die mens, direk of indirek van plante afhanklik is. Boonop het baie wetenskaplike studies oor plante ons kennis van biologie in die algemeen verbreed, dink maar aan die werk van Carl Linné, Gregor Mendel en Barbara McClintock. In die woorde van Darley (1990): 'If we feel animals are superior, it is only because we are animal chauvinists'. Dit is nie ' $n$ onbeduidende probleem nie, aangesien lewenswetenskappe sonder plantstudies 'n onvolledige beeld van die studieveld verskaf en 'n gebrekkige fokus op plante die realiteit van die holistiese aard van die lewenswetenskappe verwring (Hershey 2002).

Bogenoemde bespreking moet geensins gesien word as 'n beskuldinging teenoor dierkundiges nie. Hershey (1996) het trouens in sy ondersoek na die geskiedkundige oorsake van soösentrisme en soöchauvenisme gevind dat die blaam vir hierdie verskynsels nie voor die deur van dierkundiges gelê moet word nie, maar dat plantkundiges self die afgelope eeu bygedra het tot die geleidelike wegkwyn van die gewildheid van plantkunde. Dit is dus die taak van plantkundiges self om die wonder van hulle vakgebied aan die lig te bring en om 'n positiewe gesindheid teenoor en lewenslange belangstelling in plante by leerders en die publiek te skep.

Wandersee en Schussler (2001) het aangetoon dat slegs 7\% van skoolkinders 'n spontane belangstelling in plante toon, dat die meerderheid dierestudies bo plantstudies verkies, en dat meisies baie meer as seuns in plante belangstel. Flannery (1991) meen dat die voorkeur vir dierestudies verklaar kan word aan die hand van die ooreenkomste tussen diere en mense: hulle beweeg, hulle eet gereeld, het gesigte met oë en het interessante gedragspatrone met lewensiklusse wat maklik waargeneem kan word (paring, geboorte en die versorging van kleintjies). Diere het ook dikwels interaksie met mense.
Hershey (2002) beweer dat Plantkundelesse op uiters tegniese en vervelige maniere onderrig word en dat plantstudies as droog en kompleks beskou word. Die feit dat Plantkunde in skole afgeskeep word, word dikwels aan die inherente oninteressantheid van plante en plantstudies toegeskryf, maar hierdie wanopvatting word gou weerlê as daar in ag geneem word dat plante veel minder kompleks as diere is. Dit is maklik om plante te kweek vir ondersoek en eksperimentering of selfs net vir die estetiese waarde van plante in 'n klaskamer. Droë en oninteressante lesse oor plante is dus nie 'n inherente kenmerk van Plantkunde nie, maar 'n kombinasie van kurrikulering en pedagogiek. Hershey (1996) verskaf 'n indrukwekkende lys van voorbeelde waar onderwysers met 'n bietjie kreatiwiteit en 'n paar ekstra insette, dit reggekry het om plantstudies interessant te maak vir hulle leerders. Leerders kan bewus gemaak word van plante se unieke struktuur en funksies. In die klaskamer kan leerders se aangetrokkenheid tot beweging maklik geëksploiteer word, deur te eksperimenteer op plante wat bekend is vir hulle opvallende bewegings, soos die kruidjie-roer-my-nie (Mimosa pudica) en die gebedsplant (Maranta leuconeura), alhoewel leerders bewus gemaak moet word dat sodanige beweging slegs een aspek van die wonder van plante se unieke struktuur en funksies is. Plante wek ook nie dieselfde weersin wat eksperimentering op diere in klaskamers wek nie.

Volgens Hershey (1996) is die onderrigmateriaal wat in Plantkunde gebruik word ook deels vir die ondermyning van plantstudies verantwoordelik. Hershey (1996) skryf sommige van die probleme toe aan die feit dat baie van die skrywers van algemene Biologiehandboeke min of geen agtergrond in Plantkunde het nie en wys ook daarop dat baie van die handboeke en selfs van die kurrikula beduidende foute bevat wat na wanopvattings by leerders lei. Een gevolg is dat sommige van die wanopvattings soveel keer in verskillende handboeke herhaal word dat dit nou algemeen aanvaar word as feitelik korrekte inligting. Daar is sover vasgestel kon word geen Suid-Afrikaanse studies oor die kwaliteit en akkuraatheid van Plantkunde in die Kurrikulum en Assesseringsdokumente vir Graad R - 12 (DBO 2011) of enige plaaslik geskrewe handboeke gedoen nie en dit is nie bekend of hierdie bronne dieselfde gebreke toon nie.

Hierdie studie is deel van 'n groter projek wat poog om vas te stel wat die status van Plantkunde in Suid-Afrikaanse skole is. In dié deel van die studie is probeer om uit te vind of plantblindheid, soöchauvinisme en soösentrisme' $n$ probleem is in sekondêre skole in Tshwane (Pretoria) en in hoe 'n mate Plantkunde in skole relevant vir onderwysers en leerders is. Daar is dus gepoog om die houding van onderwysers en leerders teenoor die vak te bepaal.

\section{Navorsingsmetode}

Die studie het hoofsaaklik 'n kwalitatiewe benadering gevolg in die interpretatiewe paradigma, met ' $n$ veelvuldige 
gevallestudie-ontwerp (Henning, Van Rensburg \& Smit 2004). Hierdie ontwerp het dit moontlik gemaak om ryk beskrywende data te bekom oor die persepsies van onderwysers met betrekking tot die onderrig en leer van Plantkunde, asook beperkte data oor die voorkeure en persepsies van leerders in Lewenswetenskappe-klaskamers.

Data is ingesamel volgens die etiese vereistes en met die toestemming van die Etiese Komitee van die Fakulteit Opvoedkunde van die Universiteit van Pretoria en die Gautengse Departement van Onderwys. Toestemming is eers van die skoolhoofde verkry voordat die onderwysers en leerders by die ondersoek betrek is. Semigestruktureerde onderhoude is met 13 hoërskoolonderwysers gevoer. Die insluiting van Lewenswetenskappe-onderwysers met tussen 6 en 32 jaar ondervinding het verseker dat deelnemers uit hulle wye ervaringsveld bydraes tot die navorsing kon maak. Deelname was vrywillig met die versekering dat die onderwysers anoniem sal bly, dat daar nie op enige manier teen hulle gediskrimineer sal word nie en dat hulle enige tyd tydens die onderhoude mag onttrek.

Die semigestruktureerde onderhoude het dit moontlik gemaak om hierdie onderwysers se menings in te win en om moontlike misverstande onmiddellik uit te klaar. 'n Onderhoudskedule is opgestel met vrae wat daarop gemik is om inligting in te win oor die agtergrond van die deelnemers, die onderwysers se eie houdings en ervarings tydens hulle voor- en nagraadse opleiding in Plantkunde en hulle ervarings rakende hulle onderrig van Plantkunde. Die onderwysers se menings is ook gevra oor hoe hulle dink die leerders in hulle klasse die gedeeltes in die kurrikulum ervaar wat op plante gebaseer is.

Die studie was beperk tot nege sekondêre skole (vyf Engelsmedium, drie Afrikaansmedium en een dubbelmedium in drie distrikte van Tshwane [Pretoria]) in Gauteng. Daar is nie gepoog om die data na die res van Suid-Afrika te veralgemeen nie. Vyf van die skole kan as hulpbronryk beskryf word en vier skole het hulpbrontekorte. Korrellasies tussen die beskikbare hulpbronne en die houdings van onderwysers en leerders teenoor plantkunde kon nie gevind word nie.

'n Klein groepie hoërskoolleerders is ook deur middel van 'n eenvoudige vraelys by die studie betrek. Die vraelys het van die leerders verwag om skriftelik aan te dui of hulle daarvan hou om van plante, diere, bakterieë en virusse, menslike fisiologie of ekologie te leer. Hulle is ook gevra waarvan hulle die meeste hou: Plantkunde, Dierkunde of Menslike fisiologie. Aan die einde van die vraelys is die leerders pertinent gevra of hulle meer of eerder minder van Plantkunde sou wou leer. Die vrae is gestruktureer om 'n geslote komponent in te sluit: 'Ek wens ek kon meer oor plante leer - Ja/Nee', gevolg deur 'n oop vraag 'Waarom?' om leerders se redes vir hulle antwoorde te bepaal. Die leerdervraelyste is in die leerders se eie tyd oor 'n naweek voltooi. Dit het hulle in staat gestel om die vraelys sonder haas so volledig moontlik in te vul.
Onderhoudsdata is getranskribeer en ontleed sodat die mees prominente en betekenisvolle temas uit die data gehaal kon word sonder dat dit tot vooropgestelde kategorieë beperk is.

\section{Resultate}

Die 2 manlike en 11 vroulike onderwysers in die steekproef is ervare onderwysers, wat ten tye van die onderhoude 'n gemiddeld van 18 jaar ondervinding as onderwysers gehad het. Die onderwysers is alfabetiese kodename gegee om hulle identiteite te beskerm. Vier van die onderwysers het 'n BSc-kwalifikasie (mev. B., mev. D., mev. J. en mev. L.) (met of sonder ' $n$ onderwysdiploma) en drie het B.Ed.grade (mnr. G., mev. F. en mev. M.). Hierdie grade het Plantkunde as vak ingesluit, buiten in die geval van mnr. G. wat Biologie as hoofvak gehad het. Twee onderwysers het grade in Menslike Bewegingskunde (mev. K. en mnr. I.) en mev. A. se graad in Dieetkunde het nie Plantkunde ingesluit nie. Beide mnr. I. en mev. A. het 'n leemte in hulle Plantkundekennis ervaar toe hulle begin skoolhou het en het verdere kursusse in Plantkunde by onderskeidelik Unisa en die Onderwys-Kollege vir Verdere Opleiding voltooi. Mev. E. het 'n graad in Menslike Bewegingskunde en 'n B.Sc. met Plantkunde as vak. Twee van die onderwysers het onderwysdiplomas en gevorderde diplomas (mev. C. en mev. H.) met Biologie as vak. Twee onderwysers (mev. B. en mev. L.) het honneursgrade en twee (mev. F. en mev. M.) het Meestersgrade in Opvoedkunde verwerf. $\mathrm{Al}$ die onderwysers, buiten mev. K., het dus Plantkunde as vak of as deel van Biologie tot op minstens voorgraadse vlak bestudeer envyfonderwysers (mev.B.,mev.D.,mevF.,mev.J.enmev.M.) het Plantkunde op derdejaarsvlak of selfs honneursvlak geslaag.

Daar is geen twyfel dat hierdie groep onderwysers toegewyd is en 'n positiewe houding teenoor Lewenswetenskappe het nie. Mev. M. het die vraag of sy die onderrig van Lewenswetenskappe geniet so geantwoord: 'Verskriklik! Dis my hele lewe, ek kan nie dink dat ' $n$ mens anders moet wees nie. Dit is soos 'n klomp vakke in een. Baie lekker!'

Soortgelyke reaksies is van die ander onderwysers ontvang en onderwysers voel hulle 'geroepe' om die vak aan te bied. Mev. H. se onderhoud het in die skoolvakansie, tussen ekstra klasse deur, plaasgevind. Mev. C. stel haar aftrede uit, want sy voel sy kan nog 'n verskil maak en mev. F. het bevordering van die hand gewys omdat dit haar uit haar klaskamer sou neem.

Van die onderwysers se houding teenoor die vak Plantkunde was egter nie in alle gevalle so positief nie. Die onderwysers is gevra wat hulle gunstelingvakke tydens hulle voorgraadse opleiding was. Sewe van die onderwysers het aangedui dat Mensbiologie hulle gunstelingvakinhoud tydens hulle eie opleiding was. Plantkunde was nie een van die onderwysers se eerste keuse nie, en alhoewel mnr. G. verklaar het: 'I love plant sciences', was Omgewingstudies sy gunstelingvak en beskryf hy Dierkunde glimlaggend as: 'It's beautiful. It's the best, the best'. Mev. M. het Plantkunde geniet: 'Dit was nie 
vir my leerwerk nie. In Plantkunde sal ek enigiets verorber', maar selfs sy het aanvanklik 'n voorkeur vir Dierkunde gehad. Mev. J. het tot haar eie verbasing tot die besef gekom dat sy op universiteit meer van Plantkunde as van Dierkunde gehou het: 'I went to university with the emphasis of working with animals and I enjoyed Botany a thousand times more'. Mev. B. het van beide Plantkunde en Dierkunde gehou 'want dit was so prakties'. Sy noem ook dat sy van Plantkunde hou omdat sy in medisinale plante en heling belangstel en graag verder in Plantkunde sou wou studeer. Alhoewel hierdie studie nie genoeg data opgelewer het om 'n vaste gevolgtrekking te maak nie, wil dit voorkom of studente neig om eers teen hulle tweede of derde jaar van studie 'n voorkeur vir Plantkunde ontwikkkel.

Mnr. I. het reeds ' $n$ klompie jare skoolgehou voordat hy verder gestudeer het om sy gebrekkige kennis in Plantkunde aan te vul en 'n groter waardering vir plante ontwikkel het. Voorheen was dit 'vervelig gewees omdat ek nooit die groter prentiie gesien het nie'. Hy glo dat sy kollegas nie in sy nuutgevonde waardering vir Plantkunde deel nie: 'Baie ander onderwysers ... hulle doen nie huiswerk (voorbereiding) nie - dis 'n vervelige topic.' Tog kan hy steeds nie onomwonde sê dat hy van Plantkunde hou nie: 'Ek is oukei daarmee'. Mev. H. het aanvanklik aangedui dat sy Plantkunde geniet omdat sy nie 'n probleem gehad het om die werk te verstaan nie, maar net daarna het sy erken: 'I can't say that I enjoyed it, but it was just fine, because I understood it'. Mev. E. het onomwonde verklaar dat Plantkunde die vak was wat sy die minste geniet het.

Vir onderwysers in hierdie studie het die verskil tussen die ontwikkeling van 'n passie vir plante en plantblindheid op die pedagogiek en organisasie van hulle dosente berus. Mev. F. het by dieselfde universiteit as die outeur en mev. M. gestudeer, en al drie het uitgesproke voorstanders van die vak geword. Mnr. I. het ook, nadat hy blootgestel is aan 'n goed georganiseerde, praktiese kursus, 'n groter waardering vir Plantkunde ontwikkel. Hierdie bevinding onderskryf Hershey (2002) se stelling dat goeie plantmentors die afskeep van plante kan teëwerk. Die redes vir toekomstige onderwysers se vakkeuses en die faktore wat hulle gesindhede teenoor Plantkunde op Universiteitsvlak beïnvloed, was nie 'n doelwit van hierdie studie nie, maar sal waarskynlik 'n waardevolle studie wees om te onderneem.

Die onderwysers se antroposentriese inslag het uit hulle voorkeur vir die inhoud van Mensbiologie geblyk, maar die onderwysers kon nie almal onomwonde sê dat hulle dit geniet om Plantkunde te onderrig nie. Dit stem ooreen met die aanhaling van Flannery (1987): 'I am not alone in my prejudice; to many, botany is synonymous with what is dry, complicated and uninteresting in biology'. Vir party onderwysers soos mev. C., was dit veral in die begin van hulle loopbane moeilik om Plantkunde aan te bied:

'To tell you the truth, when I started with plants ... teaching the kids was a torture to me the first year ... but as the years went by, I mastered it so well, I thought to myself, what was wrong in the first place?'
Mev. C. het onomwonde erken dat haar gebrek aan agtergrond in Plantkunde die wortel van haar probleme was. Mnr. I. onthou:

'Ek het ge-teach wat ek moes teach. Ek het nie baie ekstra myle ingesit om seker te maak die kinders verstaan dit nie. Ek het ge-teach om dit agter die rug te kry'.

Hy vind dit steeds makliker om Dierkunde aan te bied: " $\mathrm{n} \mathrm{Ou}$ is meer gemaklik, en dis my eerlike opinie, met die Dierkunde omdat Plantkunde - mense hou nie baie daarvan nie'. Hy is bewus daarvan dat sy houding teenoor die vak 'n invloed op sy onderrig kan hê: 'Jy as onderwyser self, as jy nie van plante hou nie, gaan jy nie aandag daaraan gee nie'. Mev. K. probeer om 'n positiewe benadering te hê, maar sê: 'I just think if the books make it more fun, then it will be more fun for me as well'. Mev. L. kon identifiseer waarom slegs sekere dele van plantstudies haar aantrek: 'Some parts of the plant sciences are nice and enjoyable ... those parts of plants that are applicable to everyday life situations'. Mev. A. erken ook dat sy liewer Mensfisiologie sal aanbied en 'Plantkunde sal laaste op die lys staan'. Tog kan sy ook opgewonde raak oor die Plantkunde-inhoud as sy dit as vak moet aanbied. Mev. E. se houding teenoor Plantkunde vind ook in haar onderrig uiting en sy sê: 'I don't really have a preference for that, I do what they want me to do and it's fine'. Mev. C., mnr. I., mev. K., mev. A. en mev. E. se voorgraadse opleiding het nie Plantkunde as hoofvak (dus tot op derdejaarsvlak) ingesluit nie, wat waarskynlik hulle houding teenoor Plantkunde verklaar.

Van die onderwysers, by uitstek diegene met 'n sterker agtergrond in Plantkunde, geniet dit om Plantkunde aan te bied. Hulle besef ook dat die Plantkunde-inhoud vir leerders moeilik en ontoeganklik is en dat hulle buitengewone moeite moet doen om die leerders se belangstelling te wek. Beide mev. F. en mev. M. (albei met Plantkunde tot op honneursvlak) het genoem dat hulle voorgraadse opleiding hulle goed voorberei het om Plantkunde te onderrig en hulle liefde vir Plantkunde het verskeie kere in die onderhoude na vore gekom. Albei probeer om die inhoud vir die leerders toeganklik te maak en mev. M. het verduidelik hoe sy by herhaling vir haar leerders probeer oortuig dat die proses van fotosintese 'ongelooflik' is. Sy wys haar leerders gereeld daarop dat hulle bevoorreg is om van die laer plante onder die mikroskoop te sien: 'Julle weet nie hoe ongelooflik dit is om dit te sien nie'. Sy poog om die inhoud in verband te bring met die leerders se leefwêreld, en wys gereeld vir die leerders waar relevante voorbeelde, soos byvoorbeeld ligene, in hulle omgewing voorkom. Mev D, met haar agtergrond in Plantkunde 3, beaam die voorkeur:

'... ek hou daarvan om Plantkunde aan te bied, want jy maak vir hulle 'n nuwe wêreld oop. As jy vir hom wys daar is 'n mossporangium, dan sê hy: 'Wow, I haven't seen this before.'

Sommige onderhoude is in onderwysers se klaskamers gehou en ondanks die gemak waarmee plante in die klaskamer gekweek kan word, was daar in die meeste klasse nie 'n enkele plant nie. Twee van die onderwysers het aangedui dat hulle te veel ander werk het en dat die 
versorging van plante nie 'n prioriteit is nie. Een het selfs genoem dat plante net stof versamel. In teenstelling hiermee het mev. D., mev. M. en mev. F. plante in hulle klasse wat nie net vir estetiese doeleindes gebruik word nie, maar wat ook dien as voorbeelde vir onderrig. Sommige onderwysers neem wel hulle leerders uit die klaskamer om na plante op die skoolterrein te kyk en ander (soos mnr. G. en mev. C.) neem hulle leerders na die Nasionale Botaniese Tuin. Mnr. G. koppel hierdie veldwerk aan die genot wat die vak hom bied: 'That is what I like about Life Sciences, because you are not confined in class and your kids are able to go out and bring feedback'. Mnr. I. laat die leerders self plantmateriaal op die skoolterrein versamel en sy leerders word soms na die nabygeleë stroom geneem vir praktiese lesse.

Onderwysers het eenparig aangedui dat hulle leerders nie van Plantkunde hou nie. Die uitsonderings was so opvallend dat onderwysers hierdie leerders by die naam kon identifiseer. Mev. F. beraam dat '... maklik $80 \%$ van die kinders nie van Plantkunde hou nie'. Mev. D. en mev. L. kan duidelik sien dat die leerders nie in Plantkunde belangstel nie en dat hulle die inhoud vervelig vind. Mnr. I. beaam dit: 'Dis vir hulle baie boring. Die plante is vir hulle sommer net daar'. Mev. M. veralgemeen as sy sê:

'Ek vermoed die meerderheid sien nie plante nie. Baie beslis. Daar is ander dinge wat meer aanskoulik is en dan is dit baie meer relevant. Omdat plante net daar staan, is hulle nie eintlik belangrik nie ... Hulle hou nie van plante nie, dis net hoe dit is'.

Mev. M. se leerders wil nie eens betrokke wees by tuinmaak nie, want: 'Hulle beskou dit as 'n disgrace. Dis mos minderwaardig'.

Mev. M. vrees dat hierdie plantblindheid haar leerders se beroepskeuses sal beperk:

'Hulle het geen idee dat jy 'n lewe kan maak uit plante nie ... Enige rigting in Plantkunde of Genetika of Voedseltegnologie beteken niks vir ' $n$ kind nie. Dit sal baie moeilik wees om hulle te oortuig dat daar nou ontsettend baie werksgeleenthede is'.

Mev. H. se leerders sal haar gefrustreerd vra: 'Doen ons nog steeds plante? Is ons nog nie daarmee klaar nie?' Dit is haar grootste uitdaging om die werk vir leerders interessant te maak.

Die vraelyste wat aan die leerders verskaf is, bevestig die ongewildheid van Plantkunde onder leerders. Slegs $42 \%$ van die leerders het aangedui dat hulle van Plantkunde hou; 53\% hou nie van Plantkunde nie want hulle dink dit is vervelig, $17 \%$ sê dis moeilik, $11 \%$ sê dit dien geen doel nie, $11 \%$ hou net nie van plante nie, $6 \%$ kla dat plante niks doen nie en $2 \%$ dui aan hulle kan nie aanklank vind by plante nie. Die ondersteuners van Plantkunde voer aan dat hulle dit wel interessant vind (47\%); minder as 20\% dink dis opvoedkundig, belangrik, deel van biodiversiteit en maklik om te leer en slegs 3\% dui aan hulle hou van die kompleksiteit van die inhoud, terwyl 3\% dink plante verfraai die natuur. Altesaam $78 \%$ van die leerders wil nie meer oor plante leer nie, want volgens $46 \%$ van die leerders is dit vervelig om oor plante te leer; hulle verstaan nie die fyner punte nie (34\%); dit is nie vir hulle relevant nie $(11 \%)$; dit laat hulle druip (7\%) en hulle verkies dier- en mensstudies (1\%). Die data staan in kontras met die $90 \%$ leerders wat van Mensbiologie en $85 \%$ wat van Dierbiologie hou. Daar was 'n verskil tussen die graad 8-leerders, waar 57\% aangedui het dat hulle Plantkunde geniet en $30 \%$ wou meer oor Plantkunde leer, teenoor slegs $28 \%$ van die graad 11-leerders wat die vak geniet en $15 \%$ wat meer oor Plantkunde wou leer.

Onderwysers het gesukkel om 'n mening uit te druk of plante relevant in die lewes van hulle leerders is. Vae, abstrakte antwoorde soos: 'Ja, dis nodig om suurstof te verskaf', is gegee. Mev. M. het dit goed opgesom: 'Ja, dit (plante) het niks met hulle te doen nie' en mev. F. voel dat Plantkunde nie nou vir die leerders relevant is nie, byvoorbeeld die mikroskopiese strukture soos die sporangium van die mos. Tog voel sy dat dit sommige leerders se belangstelling geprikkel het wat die diversiteit van plante betref. In teenstelling hiermee was dit baie maklik vir die onderwysers om aan te dui hoe Mensbiologie relevansie in die leerders se lewes het. Om een onderwyser aan te haal:

'Because the kids relate to it. I mean, if you discuss something about digestion, its like the kids say, "My goodness, I'm eating every day", so now they realise what happens inside my body. So it is by far the most interesting and the kids enjoy it by far the most'.

'n Paar verwysings na soösentrisme en soöchauvinisme is gemaak, buiten die antroposentriese voorkeur vir die inhoud van Mensbiologie wat by beide die onderwysers en leerders voorkom. Mev. H. voel dat haar leerders Lewenswetenskappe net met mens- en dierinhoud, maar nie met plantinhoud assosieer nie. Mev. A. het bevestig dat die leerders slegs voorbeelde van diere gebruik wanneer hulle oor onderwerpe soos die kenmerke van lewe of diversiteit van organismes uitgevra word en mev. D. skryf soöchauvinisme toe aan die onvermoë van jongmense om werklik te sien wat om hulle aangaan: 'Kinders is nie observerend nie'.

Volgens mev. F. en mev. M. het leerders en hulle ouers ook dikwels 'n wanindruk van die vak wat tydens die laer grade gevorm word. Die verwagting is dat dit 'n 'stopvak' is waar die leerders van 'visse en die padda en die slak en die voël' leer; nie van plante, organiese verbindings en biochemiese prosesse nie. Een van mev. F. se leerders het tydens 'n les oor DNS reguit vir haar gesê: 'Juffrou, maar hierdie is nie Biologie nie!'.

Die onderwysers het heelwat spesifieke probleme geïdentifiseer wat die onderrig van Plantkunde in skole negatief beïnvloed. Eerstens is daar te min tyd om Plantkunde tot sy reg te laat kom, en onderwysers voel hulle het nie tyd om die inhoud toeganklik vir die leerders te maak nie. Mev. E. dink dat die leerders dele van die Lewenswetenskappe maklik verstaan, maar dat Plantkunde moeilik is en dat die werk stapsgewys onderrig moet word, 'n strategie wat die leerders se belangstelling prikkel, maar wat nie in die huidige skoolopset moontlik is nie. Sy erken: 'We tend to go 
over the Botany as quickly as we can that the kids get the overall impression'.

Volgens mev. C. en mnr. I. is die leerders se agtergrond en voorkennis in die Plantkunde gebrekkig. Leerders vind Plantkunde moeilik, en dit is duidelik dat hulle veral die moeiliker dele van die kurrikulum, soos fotosintese en generasiewisseling, met die vak assosieer (mev. F., mev. C. en mev. M.). Die feit dat die leerders nie bekend is met genoegsame plantkundige inhoud nie, gekoppel aan die gebrek aan tyd om remediëring van gebrekkige of afwesige agtergrondkennis te doen, maak dit moeilik om die leerders se belangstelling in die vak te prikkel. Anders as ander aspekte van Lewenswetenskappe, word die Plantkunde-inhoud ook met 'n geweldige groot getal vakterme vereenselwig. Hierdie terminologie ontmoedig die leerders.

Die onderwysers was dit eens dat die vak prakties aangebied moet word en dat die leerders die werk slegs kan verstaan as hulle self eksperimente uitvoer of eksemplare bestudeer. Mnr. I. onthou dat praktiese werk hom in staat gestel het om die teoretiese werk vir die eerste keer te verstaan en dit het by hom 'n groter waardering vir Plantkunde gekweek. Mev. F. kan na meer as dertig jaar in die onderwys nog haar voorgraadse praktiese klasse helder oproep. Hierdie ervarings en die ondervinding wat hulle deur die jare opgedoen het, moedig die onderwysers aan om self baie praktiese werk in hulle onderrig te gebruik. Ondanks 'n bewustheid van die waarde van praktiese oefeninge, het 'n paar onderwysers aangedui dat praktiese werk die hoeveelheid voorbereiding wat hulle moet doen, beduidend verhoog. Mev. C. voel dat praktiese werk 'n groot hoeveelheid beplanning verg en dat dit haar werkslading, saam met die oorvol kurrikulum en die vereistes van 'n lang skooldag, ondraaglik maak. Haar skool het, soos vele ander, nie genoegsame hulpbronne soos toerusting of 'n laboratoriumassistent nie.

Onderwysers kan improviseer of van maklik bekombare voorbeelde in hulle plaaslike omgewing gebruik maak. Leerders kan, anders as in die Dierkunde, buitentoe gaan en eksemplare maklik in die hande kry. Mev. E. se leerders het na so 'n besoek aan die skool se tuin die volgende dag met blare, sade, heelwat vrae en belangstelling teruggekom klas toe. Mev. H. gebruik die paar plante wat sy in die klas het om stadige prosesse soos fototropisme te demonstreer en mnr. I. sal die leerders dikwels sommer stuur om eksemplare op die skoolterrein te gaan versamel. Mev. H se skool het genoegsame toerusting waarvan sy wel gebruik maak, asook 'n laboratoriumassistent, maar sy voeg vinnig by: 'As die tyd dit toelaat'. Nogtans sukkel sy soms om eksemplare soos manlike denneboomkeëls in die hande te kry. Gewone skoolperiodes is ook te kort om die prakties te voltooi en moet smiddae na skool, of in vakansietye, gedoen word. Mev. F. noem dat haar skool wel mikroskope het, maar dat die groot klasse beteken dat vyf kinders een mikroskoop moet deel en dat daar ' $n$ tekort is aan sommige voorbereide mikroskoopplaatjies soos die argegonium van die den.

\section{Bevindinge en Bespreking}

Die onderwysers in hierdie studie het gewissel van uitgesproke positief tot negatief teenoor Plantkunde, soortgelyk as wat gevind is by onderwysers in ander lande. Reeds in 1956 het Fuller die mening uitgespreek dat die blaam vir hierdie gebrek aan liefde vir die vak voor die deur van plantkundiges self gelê moet word en in 2002 het Hershey hierdie aantyging onderskryf in sy artikel 'Plant blindness: We have met the enemy and He is Us'. Ost en Yager (1993) het 'n geldige punt as hulle voorstel dat Plantkunde op voorgraadse vlak so aangebied moet word dat die belangstelling van diegene wat 'n enkele Plantkunde-kursus doen, ook gewek word. In die huidige studie was dit opvallend dat die mees negatiewe houdings teenoor Plantkunde by daardie onderwysers met die minste Plantkunde-inhoud in hulle voorgraadse opleiding voorgekom het. In onderwysersopleiding sal dit ook beteken dat 'n onderwyser se belangstelling in plante na die leerders oorgedra kan word. Die data het tog aanduidings gegee dat die kwaliteit van Plantkundeopleiding in sommige instellings die blindheid van sommige van die onderwysers in die studie genees het. As die getal jare wat hierdie onderwysers egter reeds by onderwys betrokke is, in ag geneem word, kan daar nie afleidings gemaak word oor die huidige gehalte van onderwysersopleiding nie.

Ditwilvoorkomasofdiemeerderheid leerdersnievanPlantkunde hou nie. Die Kurrikulum en Assesseringsbeleidsverklarings (DBO 2011:4) stel as doelwit dat die leerders nie net kennis en vaardighede moet verwerf nie, maar ook waardes wat nodig is vir selfvervulling, 'n verwysing na die affektiewe domein. Onderwysers behoort dus ook op affektiewe vlak 'n waardering vir die vak by die leerders te ontwikkel (Botha 2012). Tans bevorder die Plantkunde-inhoud en die onderrig daarvan in Lewenswetenskappe nie die vervulling van hierdie doelwit nie. Krathwohl, Bloom en Masia (1964) se taksonomie van die affektiewe domein beskryf vyf hoofkriteria vir die evaluering van die uitkomste in die affektiewe domein. Die hoofkategorieë word beskryf as ontvanklikheid, respondering, waardebelewing, organisasie van'n waardestelsel en internalisering na'n waardekompleks. Die eerste kategorie, ontvanklikheid, behels dat die leerders bewus is van verskynsels en fenomene wat aangebied word en dat hulle bereid is om daarvan kennis te neem. Verdere vlakke word gekenmerk deur aktiewe deelname, 'n verbintenis tot waardes, die organisasie van verwantskappe tussen waardes en laastens die integrasie en toepassing van gesindhede in 'n wêreldbeskouing. Die data toon dat baie leerders beswaarlik aan die kriteria van die eerste kategorie voldoen.

Dit is ook duidelik dat die inhoud van Lewenswetenskappe as onderskeibare, losstaande eenhede aangebied en geleer word en nie as 'n holistiese eenheid nie. Smuts (1927:342) beskryf holisme as die neiging in die natuur om 'n geheel te vorm wat groter is as die som van die dele. Onderwysers en leerders kon Plantkunde-inhoud uitsonder as 'vervelig' 
en 'moeilik', maar min het dit as 'n noodsaaklike deel van die geheel van Lewenswetenskappe beskou. Die gebrek aan 'n holistiese benadering het waarskynlik bygedra tot die probleme wat onderwysers gehad het om die relevansie van die Plantkunde-inhoud vir hulle leerders te beskryf. Alhoewel baie van die belangrike kwessies in die mens se moderne bestaan nie direk in tradisionele lewenswetenskappe- of biologiekurrikula aangepak word nie (Ost \& Yager 1993), kan onderwysers nog binne die grense van sulke kurrikula die verband met hierdie kwessies trek om die inhoud van Plantkunde as vak in ' $n$ breër, meer holistiese konteks te plaas.

Alhoewel die data 'n baie negatiewe beeld skets oor Plantkunde in die skole wat in die steekproef ingesluit is, kan 'n verhoogde bewustheid van die huidige stand van Plantkunde daartoe lei dat stappe geneem word om positiewe veranderinge teweeg te bring. Die kurrikulum en onderrig van Plantkunde is vir die meeste leerders nie relevant nie. Dit is nie moeilik om die relevansie en daarmee saam die interessantheid van plantstudies te verhoog nie, insluitende die gebruik van insette buite die enge beperking van handboeke, die gebruik van lewende plante, 'hands-on', oftewel praktiese aktiwiteite, en die oordrag van die onderwyser se opgewondenheid oor en waardering vir plante (Hershey 1996). 'n Groot aantal konsepte waaraan leerders blootgestel word, kan prakties toegepas word, maar die onvermoë van onderwysers om die vakinhoud in verband te bring met die leerders se leefwêreld is waarskynlik die gevolg van 'n gebrek aan tyd, beplanning en opleiding, asook soösentrisme, soöchauvinisme en plantblindheid. Hershey (1996) stel voor dat maklik bekombare plante en nie onbekende plante nie as eksemplare gebruik word. Verder kan onderwysers die relevansie van plantkundige verskynsels uitdruklik uitwys, byvoorbeeld dat fototropisme implikasies het vir enige huisplant wat slegs van een kant belig is, dat die gevolge van waterverhoudings sigbaar word elke keer wanneer plante verwelk weens 'n watergebrek, dat voedingstekorte sigbaar word in huisplante wat nie toegang het tot die regte minerale nie en dat enige gebalanseerde bord kos die moontlikheid van 'n gesprek oor eetbare plante bied, soos waarvandaan dit kom en hoe dit vermeerder en verbou word. Plantvermeerdering kan ook op 'n opwindende wyse aangebied word, maar soos een vakadviseur onlangs aan my gesê het: Baie Suid-Afrikaanse leerders voel dat hulle een keer te veel 'n ontkiemende boontjiepit moes bestudeer het. Die teenoorgestelde kom egter ook voor, waar sommige studente in hulle voorgraadse studies nog nooit 'n enkele saad laat ontkiem het nie.

Hierdie studie het nie probeer om uit te vind hoe ander mense, buiten onderwysers en leerders, oor Plantkunde voel nie. Die groot aantal kwekerye wat die afgelope jare oopgemaak het, die bestaan van heelparty plantverenigings en die oënskynlike gewildheid van botaniese tuine kan daarop dui dat die algemene publiek wel 'n liefde vir Plantkunde het.

\section{Slotsom}

Die voordele wat plante aan die mens bied, insluitend die vele tradisionele gebruike van plante, die gebruik van plante in rigtings soos biotegnologie en die studie van fundamentele lewensprosesse wat dikwels op plante gebaseer is, sal moeilik gehandhaaf kan word as die studie van plante nie in stand gehou word nie. Verder is baie van die grootste uitdagings van die 21ste eeu, insluitende ontbossing, aardsverwarming, voedselsekuriteit, die invloed van indringerspesies en die ontdekking van nuwe farmaseutiese middels, gekoppel aan plante. Dit is dus nie vergesog om die stelling te maak dat die moderne beskawing op die suksesvolle en volgehoue kultivering van plante berus nie (National Research Council 1992).

Toekomstige Lewenswetenskappe-onderwysers wat blootgestel word aan vooroordele teenoor plante kan self bevooroordeeld raak (Hershey 1996). 'n Negatiewe gesindheid teenoor ' $n$ vak kan tot gebrekkige belangstelling daarin lei en veroorsaak dat studente dit op tersiêre vlak vermy. Hierteenoor kan 'n positiewe gesindheid 'n lewenslange belangstelling in die vak aanwakker (Simpson \& Oliver 1990). Daar rus dus 'n verantwoordelikheid op diegene wat Lewenswetenskappe-onderwysers oplei om plantblindheid, soösentrisme en soöchauvinisme uitdruklik aan te pak en teen te werk.

\section{Erkenning}

Die outeur spreek haar dank uit teenoor die volgende studente wat tot die datainsameling bygedra het: mnr. T.B. Bodaba, mev. M.A. Moabelo en mev. E. Wolff (Rudolph). Elke student het twee onderhoude gevoer en getranskribeer. Mev Wolff het gehelp om die vraelyste in te samel en te analiseer.

\section{Mededingende belange}

Die outeur verklaar hiermee dat sy geen finansiële of persoonlike verbintenis het met enige party wat haar in die skryf van hierdie artikel voordelig of nadelig kon beïnvloed nie.

\section{Literatuurrverwysings}

Barman, C.R., Stein, M., McNair, S. \& Barman, N.S., 2006, 'Students' ideas about plants and plant growth', The American Biology Teacher 68(2), 73-79. http:// dx.doi.org/10.1662/0002-7685(2006)068[0073:SIAPPG]2.0.CO;2

Botha, M.L., 2012, 'Lewenswetenskappe-onderwys in die een-en-twintigste eeu: ' $n$ Paradigmaskuif', Suid-Afrikaanse Tydskrif vir Natuurwetenskap en Tegnologie 31(1), Art. \#382, 7 pages. http://dx.doi.org/10.4102/satnt.v31i1.382

Bozniak, E.C., 1994, 'Challenges facing plant biology programs', Plant Science Bulletin 40(2), 42-46.

Darley, W.M., 1990, 'The essence of "plantness"', The American Biology Teacher 52, 354-357. http://dx.doi.org/10.2307/4449132

Departement van Basiese Onderwys, 2011, Kurrikulum en Assesseringsbeleidsverklaring Graad 10-12 Lewenswetenskappe, Staatsdrukkery, Pretoria.

Donaldson, J.S., 2010, 'Encephalartos middelburgensis, The IUCN red list of threatened species, Version 2014.3', viewed 11 November 2014, from http://www.iucnredlist. org/details/41893/0

Dougherty, J.W.D., 1979, 'Learning names for plants and plants for names', Anthropological linguistics, 21, 289-315.

FAO, WFP \& IFAD, 2012, The state of food insecurity in the world 2012. Economic growth is necessary but not sufficient to accelerate reduction of hunger and malnutrition, FAO, Rome. 
Flannery, M.C., 1987, 'In the flower garden', The American Biology Teacher 49, 310-313. http://dx.doi.org/10.2307/4448529

Flannery, M.C., 1991, 'Considering plants', The American Biology Teacher 53, 306-309. http://dx.doi.org/10.2307/4449303

Fuller, H.J., 1956, 'The odour of Botany', American Journal of Botany 43(7), 544-547. http://dx.doi.org/10.2307/2438897

Henning, E., Van Rensburg, W. \& Smit, B., 2004, Finding your way in qualitative research, pp 19-22. Van Schaik, Pretoria.

Hershey, D.R., 1996, 'An historical perspective on problems in botany teaching', The American Biology Teacher 58, 340-347. http://dx.doi.org/10.2307/4450174

Hershey, D.R., 2002, 'Plant blindness: We have met the enemy and He is Us', Plant Science Bulletin 48(3), 78-84.

Krathwohl, D.R., Bloom, B.S. \& Masia, B.B., 1964, Taxonomy of educational objectives: Handbook II: Affective domain, David McKay Co, New York, NY.

National Research Council (US), 1992, 'Plant biology research and training for the 21st century', Committee on examination of plant science esearch programs in the United States, National Academies Press (US), Washington, DC

Ost, D.H. \& Yager, R.E., 1993, 'Biology, STS and the next steps in program design and curriculum development', The American Biology Teacher 55(5), 282-287. http:// dx.doi.org/10.2307/4449660
Pimentel, D. \& Pimentel, M., 2003, 'Sustainability of meat-based and plant-based diets and the environment', American Journal of Clinical Nutrition 78 (Suppl), $6605-35$

Schneekloth, L.H., 1989. 'Where did you go? The forest. What did you see? Nothing', Children's Environments Quarterly 6(1) Spring, 14-17.

Simpson, R. \& Oliver, J., 1990, 'A summary of major influences on attitude toward and achievement in science among adolescent students', Science Education 74, 1-18, viewed 08 December 2014, from http://dx.doi.org/10.1002/ sce. 3730740102

Smuts, J., 1927, Holism and evolution, Macmillan, New York.

South African National Biodiversity Institute, 2014, 'Draft Biodiversity Management Plan - Species for 11 critically endangered and 4 endangered Encephalartos species', Encephalartos 117 (September), 10-49.

University of Exeter, 2014, 'Why plants in the office makes us more productive', Science Daily, viewed 01 September 2014, from http://www.sciencedaily.com/ releases/2014/09/140901090735.htm

Wandersee, J.H. \& Schussler, E.E., 1999, 'Preventing plant blindness', The American Biology Teacher 61, 84-86. http://dx.doi.org/10.2307/4450624

Wandersee, J.H. \& Schussler, E.E. 2001., 'Toward a theory of plant blindness', Plant Science Bulletin 47(1), 2-9. 